\title{
Revitalization of Slum Area in Semarang City with Thematic Village Program A Case Study in Bandarharjo Village, Indonesia
}

\author{
Hartuti Purnaweni \\ Department of Public Administration \\ Diponegoro University \\ Semarang, Indonesia \\ hartutipurnaweni@gmail.com
}

\begin{abstract}
Each city in Indonesia has slum area, including in Semarang. Semarang has $\mathbf{4 1 5}$ hectares of slum area, scattered in 64 villages in 15 sub districts out of 18 sub districts all over Semarang City. Aiming at parts of solving this problem, Semarang Municipal government responding with Program of Thematic Village. This research was conducted in Bandarharjo Village, which is among the worst slum areas in Semarang City. Research was done by interview and secondary data. It is found that perception about this program is varied, ranging from positive to skeptical. However, the government is committed to this program. It is suggested that the public private partnership and participatory planning is used to make this program successful.
\end{abstract}

Keywords: slum area; revitalization; fish processing area; thematic kampong

\section{INTRODUCTION}

Each city in Indonesia has slum area which should be minimized. Goswami and Kanho [1] stated that the appearance of slums may be seen as a byproduct in the process of urbanization. The people fall in low income group is generally migrants and the local poor. Majority of slum people are living in poor quality housing where the absence of basic services and facilities is significant [2]. Those who are able to find jobs and enough earning for living will live decently. However, those are unable are forced to live in slum areas.

Usually slums areas are characterized with improper and minimum facilities in terms of housing, sanitation and other facilities. In general, slum areas are areas in which more than one housing compound which has in order housing, heavily populated, improper housing condition, lack of facilities [3]

It appears as a social problem including in Semarang. As the capital city of Central Java, Semarang is a regional centre of economic growth, having also both puss and pull factors of its hinterland areas [4]. Many people come to Semarang, pushed by several factors such as the lack of job opportunity in their villages, no land or minimum land ownership. They

Corresponding author: Hartuti Purnaweni are also pulled by many factors such as job opportunity, and expectation of better economic condition. Since these people are usually lack of skill needed to live in a big city like Semarang, many of them are pushed to live in slum area, such as in Bandarharjo village.

Semarang also has slum areas as a result of its position as center of growth for some areas, therefore attracting people to come. Semarang has 415 hectares of slum area, scattered in 64 villages in 15 sub districts (kecamatan) out of 18 sub districts all over Semarang City [5].

Aiming at parts of solving this problem, Semarang Municipal government responding with among others the Program of Thematic Village (Kampong Tematik). According to the Mayor of Semarang, Hendi Budiarto, the municipal government is obliged for the people's welfare including in housing needs. They have to have programs of abolishing or revitalizing slum areas in Semarang City. According to the Mayor, problem solving for slum areas development is through three efforts, namely: (a) revitalization; (b) facilities, and (c) persuasion [6].

Therefore, it is interesting to know how is the implementation of Program of Thematic Village in Semarang.

The aim of this article is to analyze Thematic Village Program in Bandarharjo Village, Semarang City in terms of: (a) Perception over Thematic Village Program; (b) Commitment of Semarang Municipal Government in implementing the Thematic Village Program

\section{RESEARCH METHOD}

This is a descriptive qualitative article, using qualitative analyses. Primary data was gathered through interview and observation. Secondary data was gathered through finding published articles. Interview was conducted to Head of Bandarharjo Village and his staff, and also the inhabitants of Bandarharjo. Bandarharjo was chosen for location for location of this research because it is among the worst slum areas in Semarang City and is target of revitalization through Program of Thematic Village. 


\section{RESULTS AND DISCUSSION}

In this Program of Thematic Village scheme, each district (kecamatan) in Semarang City which consists of several kampongs (kelurahan) has to make three concepts kampong or village. The underlying spirits of this program are: First, creating better environment with better roads and environment, go green spirit. Secondly, since there are various potencies in these areas, the government wants to make these areas as thematic kampong. The Mayor believes that there are many activities can be done, including boosting potencies such as small-scale business, better societal life, and therefore creating more conducive city for development. Therefore the government allocates two hundred million rupiahs (Rp 200.000.000,-) for each kampong, for the realization of this thematic village program since 2016 .

Bandarharjo village is located in the northern part of Semarang City, consisting of mostly coastal area, close to the very busy Tanjung Mas seaport. Therefore, most of the inhabitants in Bandarharjo village are workers in the port and the surrounding industries. Consequently, many of the people are low income communities. Bandarharjo village is even stated as the highest area with slum in Semarang City. The selected theme in Bandarjo is: Bandarharjo as a Culinary Village.

The current condition of people in Bandarharjo village is as follows:

Table 1. Population by Sex

\begin{tabular}{|c|r|}
\hline Sex & $\begin{array}{c}\text { Total } \\
\text { Population }\end{array}$ \\
\hline Male & 10,028 \\
\hline Female & 10,183 \\
\hline Total & 20,211 \\
\hline
\end{tabular}

The number of heads of family in Bandarharjo are 4.434. The number of women and men in the village is almost the same, with slightly more women than men. Most of the inhabitants are high school graduates.

Table 2. Population by Education Level

\begin{tabular}{|c|c|r|}
\hline No & Education & $\begin{array}{c}\text { Total } \\
\text { (population) }\end{array}$ \\
\hline 1 & $\begin{array}{c}\text { Elementary school } \\
\text { graduates }\end{array}$ & 3,791 \\
\hline 2 & $\begin{array}{c}\text { Secondary school } \\
\text { graduates }\end{array}$ & 4,052 \\
\hline 3 & $\begin{array}{c}\text { Highschool } \\
\text { graduates }\end{array}$ & 6,305 \\
\hline 4 & Diploma graduates & 801 \\
\hline 5 & Undergraduates & 290 \\
\hline 6 & Post Graduates & 5 \\
\hline & Total & 15,244 \\
\hline
\end{tabular}

In this program, the local government built a Culinary Café near The Fish Smoked Center. It is hoped that the location, which is known for its low environmental condition, can be revitalized. The Fish Smoked Center has been the location of kampong improvement, since the process of smoking fish has not yet follow good environmental processes.

According to interview with Head of the Village, it is hoped that by constructing café for sea food culinary café, the local people will be encouraged to look after their area better and be ready for visitors coming to this area. The go green spirit can also be implemented

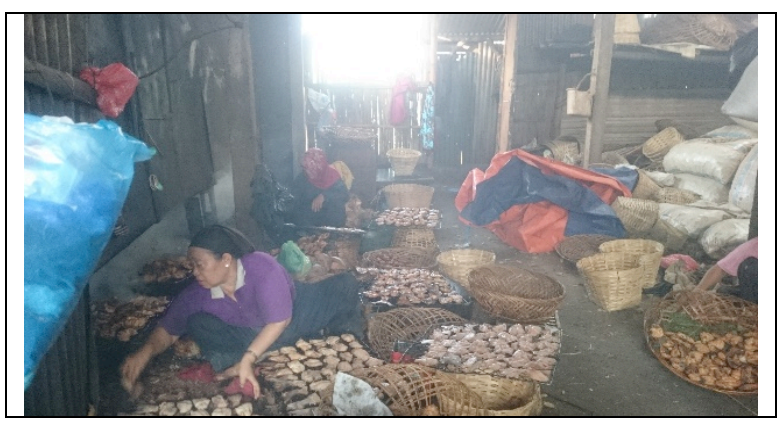

Figure 1. Smoked Fish Centre in Bandarharjo Village

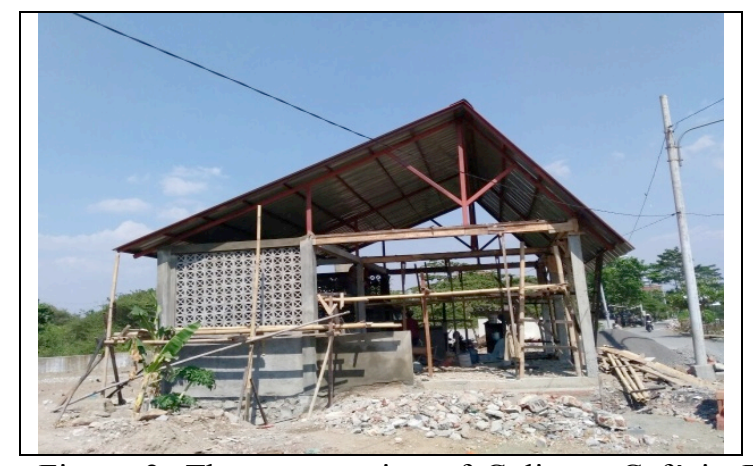

Figure 2. The construction of Culinary Café in Bandarharjo Village

\section{A. Perception over Thematic Village Program}

Perception over Thematic Village Program was quite good. Most of the informants in the Bandarharjo village are happy to implement the Thematic Village Program, hoping that this program will have benefit in improving their village, as part of revitalizing their slum areas. They are also happy with the provided fund, which is expected to boost their economic condition.

Other informants also revealed that Bandarharjo has a promising potential for creating a culinary village. Culinary business in the neighborhood will help the local people earn alternative income. While popularly considered as a slum area, Bandarharjo had apparently proved itself to be suitable for culinary spots. External supports would contribute to this area marketing the potential in culinary business, such as by public private partnership [7] 
However, some inhabitants are skeptical about this program, did not hear about this program yet, and not sure for its success since many local people are living in low economic condition. Some are aware that the program should be genuinely come from the local people; there should be strong potencies for its development, and also for its sustainability. There should be interesting activities in the thematic kampong scheme. Physical construction for the Culinary Café is easy. However, the most difficult part is the life of the people related to the selected theme.

It is suggested that the planning and implementation should apply participatory planning process as suggested by James [8]. The result should also make better the environment, as has been suggested by Lutafali and Khoja [7], which is by making a synergy between economy and ecology and with institutions of civil society acting as catalyst

Although there are potencies, there are also many problems hampering the implementation of the thematic village program in Bandarharjo, such as: the location of the Culinary Café is adjacent to the local cemetery, which according to one of the informants has the potency of decreasing the people to come to the café. However, the local government has no other location for constructing the café. The adjacent fish smoked centre should also be revitalized, to create a better environmental condition attracting people to come. Smoked fish is a popular delicacy; therefore, people are expected eager to come to the area to see the smoked fish process.

\section{B. Commitment of the Government in implementing Thematic Village Program.}

Commitment of Semarang Municipal Government and of Bandarharjo Village in implementing Thematic Village Program is varied. However, most of the informants in the governmental circle are committed to implement the program. Slums, which is viewed as illegitimate and temporary settlements, often experienced by many of its residents as permanent communities [9]. Therefore, revitalization is important to enhance local dwellers' life.

The Mayor of Semarang said that the Municipal Government is committed to revitalize slum areas to become more appropriate settlements. The government had took measures to improve the quality of kampung (village) in Semarang by promoting vary themes, as what it had been selecting and implementing ever since, such as Kampung Seni (art village), Kampung Jawi (Java village), Kampung Bandeng (milkfish village), Kampung Batik (batik village), and Kampung Pelangi (rainbow village). The latter had even been a globally viral topic featured by some international news agencies. In particular Bandarharjo, this area had been promoted as a Kampung Kuliner (culinary village).

The Municipal Government of Semarang had made efforts to manage its urban settlements, not only dealing with the physical buildings, but also with the dwellers who lived within. The government required all concerned parties, including the government itself, business community, mass media, and the local dwellers, to participate into the revitalization program of the kampung, such as suggested by Lutafall and Khoija [7]

There are many activities can be done, including boosting small-scale business potency in Bandarharjo, better societal life, and therefore creating more conducive Semarang City

\section{IV.CONCLUSION}

The target of the government of Semarang Municipality is revitalizing the city's slum areas in 2019 is with Thematic Village Program. One of the programs is constructing thematic village in each sub district. In 2016 the target is choosing three villages in each of the 16 sub districts having thematic program Bandarharjo choose Culinary Café as its thematic program. The perception over this program is good, also the commitment.

\section{REFERENCES}

[1] S. Goswami and S. Manna, "Urban Poor Living in Slums: A Case Study of Raipur City in India", Global Journal of Human Social Science Sociology \& Culture Volume 13 Issue 4, 2013

[2] T.Tanni, MJ Hasan, AK Azad, B Bakali, "State of the Environment in Slum Area: A Case Study on Khora Slum, Khulna", J. Environ. Sci. \& Natural Resources, 7(1): 295-304 2014

[3] Semarang Municipal Government, Slum Improvement Action Plan (SIAP) NUSP2 Kota Semarang, Semarang. 2016

[4] M.A, Ridlo, "Find Solution to Handling Slums Settlement in Semarang City", National Seminar on Informal Settlements and Affordable Housing, Semarang 22-23 Februari 2007.

[5] BPS (Statistical Board) of Semarang, 2016

[6] Metro Berita, 28 August 2017

[7] S.Lutafali and F. Khoja, "Economic and Ecological Partnership Revitalizing Urban Slums; A Case Study of Cairo", International Journal of Ecology \& Development, Winter Vol 18, No W11, 2011

[8] R.K. James, "From "slum clearance" to 'revitalization': planning, expertise and moral regulation in Toronto's Regent Park", Planning Perspective Vol 25, No 1, January pp. 69-86, 2010

[9] J,Thorn; T. F. Thornton and A. Helfgott, "Autonomus Adaptation to global environmental change in urban settlements; Evidence of a growing culture and innovation and revitalization in Mathare Valley Slums, Nairobi”. Global Environmental Change 31,pp. 121-131. 2015 